\title{
Impact of brand equity on customer purchasing behavior: A study of clothing industry of Iran
}

\author{
Shekofeh Sadeghi \\ Islamic Azad University of \\ Gheshm, Iran
}

\author{
Mohammad Ail Abbasi \\ Islamic Azad University of \\ Abarkooh, Iran
}

\author{
Somaye Tabatabaei \\ Islamic Azad University of \\ Firuzabad, Iran
}

\begin{abstract}
This study as a quantitative research attempts to postulate that brand equity has high potential to improve customer purchasing behavior in clothing industry of Iran. By literature review, brand equity has four components including, brand association, brand loyalty, perceived quality, and brand awareness. 400 data was gathered and analyzed. The results showed that the highest impact refers to perceived quality while the lowest impact refers to brand awareness.
\end{abstract}

Keywords: Brand Equity, Brand Association, Brand Loyalty, Perceived Quality, Purchasing Behavior, Clothing Industry, Iran

\section{INTRODUCTION}

Clothing industry is one of those industries that can grow in all of the countries across the world. Iran, also is one of those countries that has a variety of product ranges in this industry. Since, clothing is one of the high selling industries, so its growth is very critical in order to contribute country's economic growth through appropriate selling of products. It's been a while since Iranian products could not be successful to attract domestic customers. On the other hand, importing of Chinese products and also well-known western brands resulted in changes in customer's purchase behavior. Brand equity is one of the influential factors on purchase behavior (Aghaei, 2014; Kladou, S., \& Kehagias, 2013; Aaker, 1991). According to literature review, brand equity constitutes of perceived quality, brand loyalty, brand awareness and brand association. The fact that how brand equity can impact purchasing behavior in clothing industry of Iran, is the main idea of current research. Hence, this study aims to find how brand equity' components affects customer purchasing behavior in clothing industry of Iran.

\section{LITERATURE REVIEW}

Many conducted studies previously, focused on brand equity notion and all of its relevant definitions. Some of the famous researches performed before, tried to discuss "brand equity" concept as a set of assets and liabilities relevant to a specific brand for example name and symbol which can impose beneficial or detrimental effects on arising values from products and services (Yasin et al., 2007; Aakar, 1991). Moreover, Keller (1999) mentioned that brand equity is able to signify many unique marketing effects on a specific brand. Thus, by considering positive brand equity features, it can occur while customers are all willing to pay higher amounts for an interesting name disclosed to products or services which has the same quality level in comparison to other products (Bello and Hobrook, 1995). However, brand equity might be damaged while it is not effectively managed. For instance, poor product quality or customer service can have negative impacts on brand image that might lead to decrease in sales volume.

In addition, Murphy (1998), presented one of the critical examples of brand as a kind of equity and provided laws to support intellectual property. His study led to some elaborate discussions and in those countries that legal system has been developed properly, the values of a brand have been considered for customers and producers both. In order to deal with piracy, many countries set up laws to protect trademarks, patents, designs and copyrights. In addition, brand is assumed as a product that is tradable and could be evaluated through financial values (Boyle, 2003).

As shown in research conducted by (Aakar, 1991), becoming familiar with a certain brand and past purchase experiences can both impact 
customers' perception. Besides, Aakar (1991) asserted that brand equity can generate high margins by reduction in reliance and also premium pricing according to promotional activities. In addition, Aakar (1991) noted that by means of a positive image, customers will not focus on promotions in short-term anymore and instead assume the brand as a whole. He mentioned that brand equity is considered as a general concept and has to be subdivided later as four specific areas including brand loyalty, brand awareness, perceived quality and brand associations.

\subsection{Brand Awareness}

We can assume it as one of the significant attributes due to it is considered as one of the important features of brand which influences attention. There are various ideas from different scholars relevant to capability of potential customers to recall and arrange brand and making it relevant to its related product class (Aakar, 1991; Kim \& Ko, 2012). The brand awareness level is at some point linked to brand recognition and also the first brand with name in highest level possible.

Regarding the potential customers, it is necessary to know about products, thus it is one of the choices to purchase. Maybe there should be a certain level of awareness for a product before penetrating a set of considerations (Homburg et al., 2010) and rising the brand awareness could be conductive with high chance of entering to the second set (Nedungadi, 1990). Here, those brands which have more levels of awareness probably would be purchased more (Kim and Ko, 2012; Yasin et al., 2007). In addition, it will explain why customers prefer to purchase the well-known brands instead of less famous brands (Macdonald and Sharp, 2000; Hoyer and Brown, 1990).

Based on a study conducted by Keller (1999), brand awareness could be increased through a lot of repeated exposures to a brand. In order to have brand awareness there are two tasks to be done including improving the identity of brand name and relating it with the class of product. Celebrity endorsement and advertisement could be considered as a helpful tool to increase brand awareness. In a lot of studies, it was identified that advertisement is an influential device (Mackenzie et al, 1986; Tsai et al, 2007; Aghaei et al, 2014).

By above discussion, the first hypothesis of this study is formulated as follow:

\section{H1: Brand awareness affects purchasing behavior significantly and positively}

\subsection{Perceived Quality}

A lot of previously performed studies, examined perceived quality in various fields and a lot of emphasize was on many important attributes such as perceived quality. It is known as customer perception regarding superiority of products and total service quality as well (Aakar, 1991; Keller. 1999; Yasin et al., 2007).

The other researches tried to assume it through intangibles and focused on total emotions for brand as well as discussing that it is naturally subjective and noted that product specifications could have less relevant correlation to the perceived quality. The brand's perceived quality will contribute to generate value via reasoning to buy a certain product and contributing to make some differentiation for brand positioning, offering premium price strategies and motivating the channel members to operate effectively as well as expanding the extensions into new categories of brand (Aakar, 1991). Moreover, it was identified that perceived quality is a significantly important factor to define brand loyalty and repeated purchases both (Delong et al, 2004). Besides, it was understood that obtaining a satisfactory level of the perceived quality is not easy due to there are so many fast and continuous advancements in products which can improve customer expectations about quality of a product (Park et al., 2002). However, the second hypothesis of this study is as follow:

$\mathrm{H} 2$ : Perceived quality affects purchasing behavior significantly and positively

\subsection{Brand Loyalty}

The other analyzed topic in previous studies was the brand loyalty concept due to it is 
assumed as a main aspect of brand equity. Based on a study conducted by Atilgan et al (2005) it was identified that brand loyalty has both positive and negative impact on brand equity regarding certain products as well as it was shown that how it can have direct and indirect impact on brand loyalty. In case of influencing the brand loyalty, a lot of studies demonstrated that customers continue to purchase a certain brand without emphasizing on superior aspects, convenience or price of competitors (Aakar, 1991).

Also (Aakar, 1991), explained that probably loyal customers will more repeat the purchase thus it has less cost for them to keep their customers compared to attracting the potential ones. Secondly, brand loyalty can increase trade leverages. Many customers who have high levels of emotion toward a specific brand will switch to shops that sell that certain brand. Thirdly, loyal customers can influence purchase behavior of other customers to purchase that brand. So, the third hypothesis of this study is developed as follow:

\section{H3: Brand loyalty affects purchasing behavior significantly and positively}

\subsection{Brand Association}

The brand association concept inspired scholars to perform many studies on different roles of brand association. Although there are a lot of consensus parts regarding the definition of relationship between brand and memory in general (Aakar, 1991; Keller, 1999; Yasin et al, 2007), such types of researches revealed that brand equity is dependent on association of customers to brands that will lead to building a certain brand image.

These two experts asserted that brand association is a remarkably complex concept which is related to different ideas, examples, facts and also episodes which create a network of brand knowledge (Yoo et al., 2002). Moreover, regarding the tangible products, all of the qualities which intangible such as distinctiveness and innovativeness also are considered as brand associations.
In addition, Keller (1999) classified brand associations as attitudes, benefits and attributes. The attributes mean those specific product features. They could be categorized as product non-product and product related attributes. Regarding the product related attributes, all of the service or product features should be considered. In case of non-related attributes, packaging, price information, usage imagery and user imagery have to be considered.

Brand association results in value creation for both organization and the customers.

Extant research conducted by Wong (2013), Kim and Ko (2012), and Griffin et al. (2012) emphasized on the impact of brand association on customer buying behavior. So, the fourth hypothesis will be as follow:

H4: Brand association affects purchasing behavior significantly and positively

\section{METHODOLOGY}

This research applied quantitative approach (hypothesis testing). For this purpose, 400 questionnaires were distributed among customers. This research conducted on November of 2016. The scope of this study was Iranian clothing industry, so the designed questionnaires were distributed in 10 large shopping mall located in 4 largest cities of Iran (Tehran, Shiraz, Isfahan, and Mashhad). The respondents were chosen randomly from people who had come for shopping. It should be mentioned that the questionnaire were developed based on the research of Aaker (1991) and Aghaei et al. (2014). To analyze gathered data, Pearson Correlation test, and regression analysis were carried out by SPSS 22. It should be mentioned that to measure each variable 5-point Likert scale were applied. This scale was sorted from strongly disagree (1) to strongly agree (5). 


\section{RESULTS AND DISCUSSION}

The first analysis considers demographic factors. Table 1 demonstrates results achieved by demographic analysis.

Table 1: Demographic

\begin{tabular}{|l|l|l|}
\hline & Frequency & Percentage \\
\hline Gender & 212 & \\
Male & 188 & $53 \%$ \\
Female & & $47 \%$ \\
\hline Age & 78 & \\
Less than 18 & 155 & $19.5 \%$ \\
$19-25$ & 101 & $38.75 \%$ \\
$26-40$ & 66 & $25.25 \%$ \\
Greater than 45 & 148 & $16.5 \%$ \\
\hline Education & 191 & $37 \%$ \\
Diploma or below & 61 & $47.75 \%$ \\
Bachelor & & $15.25 \%$ \\
Master or higher & 203 & \\
\hline Salary & 121 & $50.75 \%$ \\
Less than 500 \$ & 76 & $30.25 \%$ \\
501-1000 \$ & & $19 \%$ \\
More than 1001\$ & & \\
\hline
\end{tabular}

Referring to the table 1, the frequency of male is greater than female. The highest frequency of age refers to the third group of respondents (155) while the lowest frequency refers to the last group (66). The maximum frequency of education refers to the respondents who have bachelor degree. Out of 400 respondents, 203 customers have salary below $500 \$$ per month while 121 of respondents receive salary between 501 and 1000\$ monthly. The lowest frequency of salary refers to people who receive more than $1001 \$$ per month.

The next analysis refers to mean analysis. Table 2 demonstrates the results of mean analysis.
Table Z Descriptive Stristics

\begin{tabular}{|c|c|c|c|c|c|c|c|}
\hline & \multirow{2}{*}{\begin{tabular}{|l} 
N \\
Statistic
\end{tabular}} & \multirow{2}{*}{$\begin{array}{l}\text { Mean } \\
\text { Statsic }\end{array}$} & \multirow{2}{*}{$\frac{\text { Sar. Deviation }}{\text { Shastic }}$} & \multicolumn{2}{|c|}{ Sheiness } & \multicolumn{2}{|l|}{ Kuntosis } \\
\hline & & & & Staisic & Std Enur & Statsisic & Sta Enot \\
\hline Perceied quaty & 100 & 31125 & 1.103437 & 344 & 122 & -9600 & 243 \\
\hline Brard Loyaty & $100^{\circ}$ & 28965 & 1.01868 & 159 & 122 & -1.262 & .243 \\
\hline Brand Ausreness & 100 & 3.0125 & 1.07781 & 251 & 122 & -1201 & .243 \\
\hline Brand Association & 190 & 30390 & 1.04182 & 103 & 12 & -1.103 & 243 \\
\hline Furchasing tehaicr & 100 & 3.1965 & 1.074 & 287 & 122 & -1.055 & .243 \\
\hline Vaid N (istised & 400 & & & & & & \\
\hline
\end{tabular}

According to the table 2, the highest mean (3.1965) refers to purchasing behavior while the lowest estimated value for mean (2.8905) refers to brand loyalty. All of the estimated values for skewness are positive, so for each variable the pick of frequency chart is located to the left direction. The negative values of kurtosis show that all of the variables have flat distribution.

\begin{tabular}{|c|c|c|c|c|c|c|}
\hline & & $P Q$ & $B L$ & $B A$ & BAsS & PB \\
\hline \multirow[t]{3}{*}{$\overline{P Q}$} & Pearson Correlation & 1 & $.254^{*}$ & $.188^{*-}$ & $.393^{*}$ & $.646^{*}$ \\
\hline & Sig. (2-tailed) & & .000 & .000 & .000 & .000 \\
\hline & $\mathrm{N}$ & 400 & 400 & 400 & 400 & 400 \\
\hline \multirow[t]{3}{*}{$\mathrm{BL}$} & Pearson Correlation & $254^{*}$ & 1 & $.125^{\circ}$ & .089 & $.275^{*}$ \\
\hline & Sig. (2-tailed) & .000 & & .012 & .076 & .000 \\
\hline & $\mathrm{N}$ & 400 & 400 & 400 & 400 & 400 \\
\hline \multirow[t]{3}{*}{$B$} & Pearson Correlation & $188^{*}$ & $.125^{\circ}$ & 1 & .038 & $.249^{-4}$ \\
\hline & Sig. (2-tailed) & .000 & .012 & & .444 & .000 \\
\hline & $\mathrm{N}$ & 400 & 400 & 400 & 400 & 400 \\
\hline \multirow[t]{3}{*}{ B AsS } & Pearson Correlation & $393^{*}$ & .089 & .038 & 1 & $.441^{*}$ \\
\hline & Sig. (2-tailed) & .000 & .076 & .444 & & .000 \\
\hline & $\mathrm{N}$ & 400 & 400 & 400 & 400 & 400 \\
\hline \multirow[t]{3}{*}{ PB } & Pearson Correlation & $.646^{*}$ & $.275^{*}$ & $.249^{*}$ & $.441^{*}$ & 1 \\
\hline & Sig. (2-tailed) & .000 & .000 & .000 & .000 & \\
\hline & $\mathrm{N}$ & 400 & 400 & 400 & 400 & 400 \\
\hline
\end{tabular}




\begin{tabular}{|c|c|c|c|c|c|c|}
\hline & & $P Q$ & BL & $B A$ & BAss & PB \\
\hline \multirow[t]{3}{*}{$\overline{P Q}$} & Pearson Conelation & 1 & $254^{\circ}$ & $188^{-}$ & $.393^{-}$ & $.646^{\circ}$ \\
\hline & Sig (2-ailed) & & .000 & .000 & .000 & .000 \\
\hline & N & 400 & 400 & 400 & 400 & 400 \\
\hline \multirow[t]{3}{*}{ BL } & Pearson Correlation & $254^{\circ}$ & 1 & $125^{5}$ & .089 & 275 \\
\hline & $\operatorname{Sin}$ (2-tailed) & 000 & & .012 & .076 & .000 \\
\hline & N & 400 & $\$ 00$ & 400 & 400 & 400 \\
\hline \multirow[t]{3}{*}{$B A$} & Pearson Conelation & $188^{-}$ & 125 & 1 & .038 & $.249^{\circ}$ \\
\hline & Sig. (2-taled) & 000 & .012 & & .444 & .000 \\
\hline & N & 400 & 400 & 400 & 400 & 400 \\
\hline \multirow[t]{3}{*}{ BAss } & Pearson Correlation & $393^{-1}$ & .089 & .038 & 1 & 441 \\
\hline & Sig. (2-aled) & 1000 & .076 & .444 & & .000 \\
\hline & N & 400 & 400 & 400 & 400 & 400 \\
\hline \multirow[t]{3}{*}{ PB } & Pearson Correlation & $646^{\prime \prime}$ & $275^{\prime \prime}$ & $249^{\prime \prime}$ & $.441^{-}$ & 1 \\
\hline & Sig. (2-taled) & 000 & .000 & .000 & .000 & \\
\hline & N & 400 & 400 & 400 & 400 & 400 \\
\hline
\end{tabular}

As shown in table 3, all of the independent variables have significant relationships with purchasing behavior. The highest estimated value (.646) refers to perceived quality while the lowest value (.188) refers to brand awareness.
Table 4. Regression Analysis

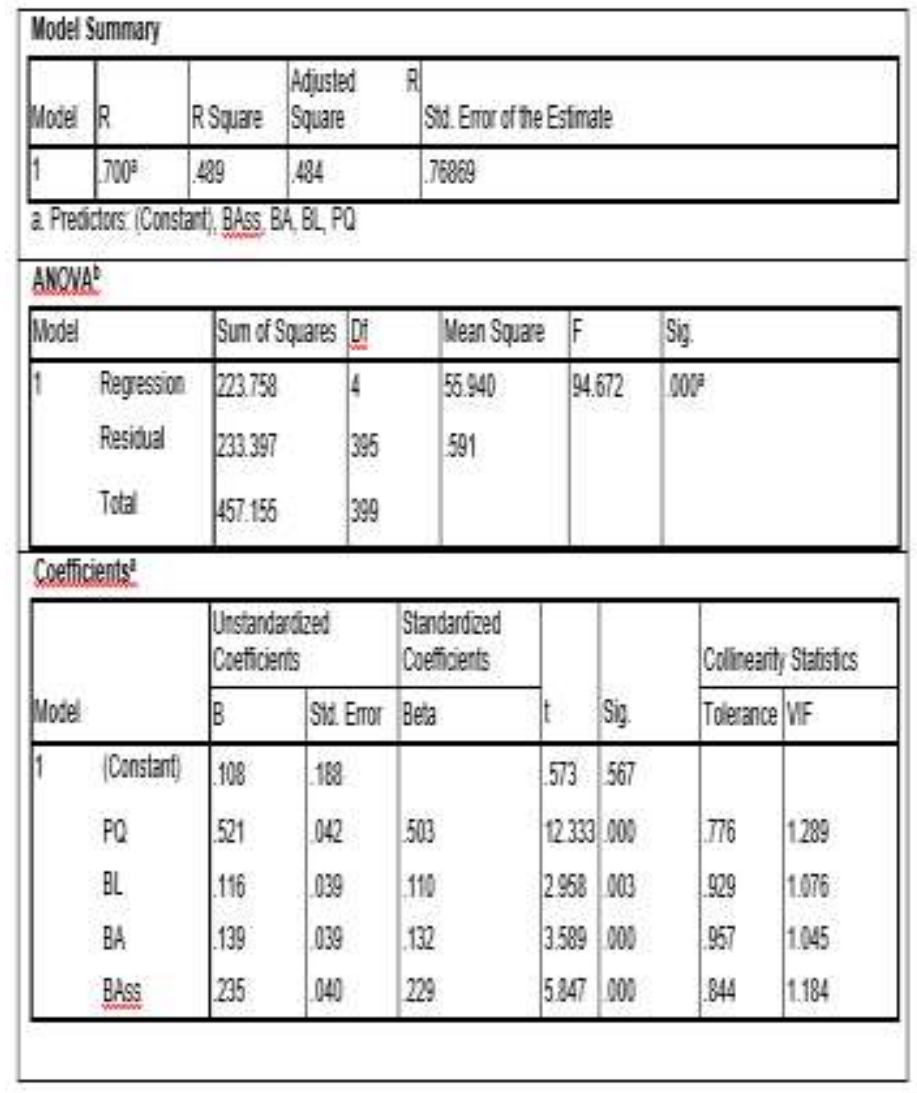

Referring to table $4, \mathrm{R}$ square is equal to .489 which means that $48.9 \%$ of variation in purchasing behavior can be accounted by brand equity's components. As shown in ANOVA table, the estimated p-value is zero, so at least one of the independent variables has significant impact on purchasing behavior. Besides, there is no multi co linearity among independent variables because all VIF are less than 5 .

We are $95 \%$ confident that brand awareness has significant effect on customer purchasing behaviors in clothing industry of Iran because $\mathrm{p}$-value is equal to zero. The estimated coefficient is equal to .139 which asserts that for every unit increase in brand awareness, purchasing behavior will go up .139 units. Consequently, the first hypothesis of this study (H1) is supported by the results.

We are $95 \%$ confident that perceived quality has significant effect on customer purchasing behaviors in clothing industry of Iran because $\mathrm{p}$-value is equal to zero. The estimated 
coefficient is equal to .521 which asserts that for every unit increase in perceived quality, purchasing behavior will go up .521 units. Consequently, the second hypothesis of this study $(\mathrm{H} 2)$ is supported by the results.

We are $95 \%$ confident that brand loyalty has significant effect on customer purchasing behaviors in clothing industry of Iran because p-value is equal to .003 (less than .05). The estimated coefficient is equal to .116 which asserts that for every unit increase in brand loyalty, purchasing behavior will go up .116 units. Consequently, the third hypothesis of this study (H3) is supported by the results.

We are $95 \%$ confident that brand association has significant effect on customer purchasing behaviors in clothing industry of Iran because p-value is equal to zero (less than .05). The estimated coefficient is equal to .235 which asserts that for every unit increase in brand association, purchasing behavior will go up .235 units. Consequently, the fourth hypothesis of this study (H4) is supported by the results

By above results, we can formulate following regression equation:

$$
\begin{aligned}
& P B=.108+.521(P Q)+.235(B A s s)+.116 \\
& (B L)+.139(B A)
\end{aligned}
$$

\section{CONCLUSION}

By the review of literature in term of marketing management, brand equity (perceived quality, brand loyalty, brand association, and brand awareness) have high potential affect customer purchasing behavior. The findings of this research also reinforce respective theories. According to the results of this study all of the brand equity's components have significant and positive impact customer purchasing behavior in clothing industry of Iran. So, Iranian company should attempt to increase their brand equity by concentrating on its components. Since the highest impact referred to the perceived quality, Iranian company needs to improve their technologies towards higher and better quality.
The results of regression analysis shows low $\mathrm{r}$ square, so future study may add another variable to improve the framework of this study.

\section{REFERENCES}

Aakar, D. A. (1991). Managing Brand Equity, Capitalized on the Value of a Brand Name.

Aghaei, M., Vahedi, E., Kahreh, M. S., \& Pirooz, M. (2014). An Examination of the Relationship between Services Marketing Mix and Brand Equity Dimensions. Procedia-Social and Behavioral Sciences, 109, 865-869.

Atilgan, E., Aksoy, S., \& Akinci, S. (2005). Determinants of the brand equity: a verification approach in the beverage industry in Turkey. Marketing intelligence \& planning, 23(3), 237-248.

Bello, D. C., \& Holbrook, M. B. (1995). Does an absence of brand equity generalize across product classes? Journal of Business Research, 34(2), 125-131.

Boyle, E. (2003). A study of entrepreneurial brand building in the manufacturing sector in the UK. Journal of product \& brand management, 12(2), 79-93.

Delong, M., Bao, M., Wu, J., Chao, H., \& Li, M. (2004). Perception of US branded apparel in Shanghai. Journal of Fashion Marketing and Management, 8(2), 141-153. Griffin, A., Gleason, G., Preiss, R., \&Shevenaugh, D. (2012). Best practice for customer satisfaction in manufacturing firms. Sloan Management Review, 36(2).

Homburg, C., Klarmann, M., \& Schmitt, J. (2010). Brand awareness in business markets: when is it related to firm performance?. International Journal of Research in Marketing, 27(3), 201-212.

Hoyer, W. D., \& Brown, S. P. (1990). Effects of brand awareness on choice for a common, repeat-purchase product. Journal of consumer research, 141-148.

Keller, L. K. (1999). Brand mantras: rationale, criteria and examples. Journal of Marketing Management, 15(13), 43-51.

Kim, A. J., \&Ko, E. (2012). Do social media marketing activities enhance customer equity? An empirical study of luxury fashion brand. Journal of Business Research, 65(10), 1480-1486.

Kladou, S., \&Kehagias, J. (2013).Assessing destination brand equity: An integrated approach. Journal of Destination Marketing \& Management.

Macdonald, E. K., \& Sharp, B. M. (2000). Brand Awareness Effects on Consumer Decision Making for a Common, Repeat Purchase Product:: A Replication. Journal of business research, 48(1), 5-15. MacKenzie, S. B., Lutz, R. J., \& Belch, G. E. (1986). The role of attitude toward the ad as a mediator of advertising effectiveness: A test of competing explanations. Journal of marketing research, 130-143. Murphy, J. (1998). What is branding?. In Brands (pp. 112). Palgrave Macmillan UK.

Nedungadi, P. (1990). Recall and consumer consideration sets: Influencing choice without altering 


\section{International Journal of Science and Engineering Applications \\ Volume 6 Issue 01, 2017, ISSN-2319-7560 (Online)}

brand evaluations. Journal of consumer research, 263276.

Park, J. W., Kim, K. H., \& Kim, J. (2002). Acceptance of brand extensions: interactive influences of product category similarity, typicality of claimed benefits, and brand relationship quality. Advances in consumer research, 29(1), 190-198.

Wong, I. A. (2013).Exploring customer equity and the role of service experience in the casino service encounter. International Journal of Hospitality Management, 32, 91-101

Yasin, N. M., Noor, M. N., \&Mohamad, O. (2007). Does image of country-of-origin matter to brand equity?. Journal of Product \& brand management, 16(1), $38-48$.

Yoo, B., \& Donthu, N. (2002). Testing cross-cultural invariance of the brand equity creation process. Journal of Product \& Brand Management, 11(6), 380-398. 